\title{
Correction to: Timing rather than user traits mediates mood sampling on smartphones
}

\author{
Beryl Noë ${ }^{1 *} \mathbb{D}$, Liam D. Turner ${ }^{1}$, David E. J. Linden ${ }^{2,3}$, Stuart M. Allen ${ }^{1}$, Gregory R. Maio ${ }^{4}$ and Roger M. Whitaker ${ }^{1}$
}

\section{Correction to: BMC Res Notes (2017) 10:481 https://doi.org/10.1186/s13104-017-2808-1}

In the original article [1] an author's name was inadvertently omitted from reference no. 7 .

Khue LM, Jarzabek S. Demonstration paper: mood selfassessment on smartphones. In: Proceedings of the conference on wireless health. ACM, New York, NY, USA. 2015. https://doi.org/10.1145/2811780.2811921.

should therefore be corrected as follows:

Khue LM, Ouh EL, Jarzabek S. Demonstration paper: mood self-assessment on smartphones. In: Proceedings of the conference on wireless health. ACM: New York; 2015. https://doi.org/10.1145/2811780.2811921.

\section{Reference \\ 1. Noë B, Turner LD, Linden DEJ, Allen SM, Maio GR, Whitaker RM. Timing rather than user traits mediates mood sampling on smartphones. BMC Res Notes. 2017;10:481. https://doi.org/10.1186/s13104-017-2808-1.}

\section{Publisher's Note}

Springer Nature remains neutral with regard to jurisdictional claims in published maps and institutional affiliations.

\begin{abstract}
Author details
${ }^{1}$ School of Computer Science and Informatics, Cardiff University, The Parade 5 Cardiff CF24 3AA, UK. ${ }^{2}$ School of Psychology, Cardiff University Brain Research Imaging Centre, Maindy Road, Cardiff CF24 4HQ, UK. ${ }^{3}$ School of Medicine, MRC Centre for Neuropsychiatric Genetics and Genomics, Maindy Road, Cardiff CF24 4HQ, UK. ${ }^{4}$ Department of Psychology, University of Bath, 10 West, Bath BA2 7AY, UK.
\end{abstract}

Published online: 28 May 2020
The original article can be found online at https://doi.org/10.1186/s1310 4-017-2808-1.

*Correspondence: NoeB@cardiff.ac.uk

1 School of Computer Science and Informatics, Cardiff University, The

Parade 5, Cardiff CF24 3AA, UK

Full list of author information is available at the end of the article

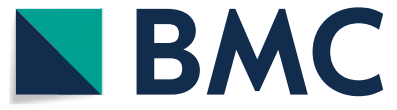

c) The Author(s) 2020. This article is licensed under a Creative Commons Attribution 4.0 International License, which permits use, sharing, adaptation, distribution and reproduction in any medium or format, as long as you give appropriate credit to the original author(s) and the source, provide a link to the Creative Commons licence, and indicate if changes were made. The images or other third party material in this article are included in the article's Creative Commons licence, unless indicated otherwise in a credit line to the material. If material is not included in the article's Creative Commons licence and your intended use is not permitted by statutory regulation or exceeds the permitted use, you will need to obtain permission directly from the copyright holder. To view a copy of this licence, visit http://creativecommons.org/licenses/by/4.0/. The Creative Commons Public Domain Dedication waiver (http://creativecommons.org/publicdomain/zero/1.0/) applies to the data made available in this article, unless otherwise stated in a credit line to the data. 